\title{
Leaf dipping as an environmental screening measure to test chemical efficacy against Bemisia tabaci on poinsettia plants
}

\author{
*A. G. S. Cuthbertson; L. F. Blackburn; P. Northing; W. Luo; R. J. C. Cannon; K. F. A. Walters
}

The Food and Environment Research Agency, York, England, UK

Received 6 August 2008; revised 5 January 2009; accepted 2 March 2009

\begin{abstract}
The screening of potential chemicals for control of Bemisia tabaci on poinsettia (Euphorbia pulcherrima c.v. Lilo Pink) plants using a leaf dipping technique was investigated. All relevant $B$. tabaci lifestages (eggs, larvae and adults) were investigated. In leaf dipping tests, Certis spraying oil was the only compound to show potential to be used as a control agent against $B$. tabaci eggs, with $81 \%$ obtained mortality. Oberon resulted in no mortality of $B$. tabaci eggs in the reported experiments. Leaf dipping against second instar and adult $B$. tabaci proved more effective for all chemical products. Dipping techniques using Majestik, Certis spraying oil and Agri$50 \mathrm{E}$ all resulted in high second instar larval mortality (93, 87 and $85.5 \%$, respectively). Certis spraying oil again resulted in a high efficacy against adult $B$. tabaci with $100 \%$ mortality obtained. The potential of the various chemicals to be incorporated into integrated pest management strategies for the control of $B$. tabaci is discussed.
\end{abstract}

Keywords: Crop; Insecticide; Integrated pest management; Plant sap; Quarantine pest

\section{INTRODUCTION}

The sweetpotato whitefly, Bemisia tabaci Gennadius (Hemiptera:Aleyrodidae), remains a worldwide pest (Landa et al., 1994; Nomikou et al., 2001) causing yield losses in many economically important crops (Fransen, 1994; Gerling and Mayer, 1996; Gerling et al., 1980). Within the UK, B. tabaci poses a threat primarily to protected vegetable crops due to the large number of virus diseases it is known to transmit (Alegbejo, 2000; Jones, 2003). The pest can also cause damage by direct feeding on plant sap and indirect damage through contamination of leaves by honeydew excretion (Naranjo et al., 2002; Nomikou et al., 2001). The species has been intercepted annually in the UK on imported plant material since 1987, and statutory action aimed at eradication is taken whenever it is found (Cheek and McDonald, 1994). Eradication of whitefly has normally relied on treatments using chemical insecticides. Within the UK the active ingredients currently used against B. tabaci are imidacloprid, spiromesifen and thiacloprid. However, the continued development of whitefly populations

*Corresponding Author Email: andrew.cuthbertson@fera.gsi.gov.uk Tel.: +44 1904462 201; Fax: +44 1904462111 resistant to chemical insecticides (Ahmad et al., 2002; Cahill et al., 1994; 1996; Cannon et al., 2005), indicates that further chemicals and or biological agents must be investigated for their efficacy against B. tabaci (De Barro, 1995; Dennehy and Williams, 1997; Osborne and Landa, 1992; Prabhaker et al., 1985). To continue providing horticultural consultants and protected ornamental and horticultural growers with sufficient information on which to base commercially viable control decisions, data on the efficacy of a wider range of insecticides for the control of all lifestages of B. tabaci (eggs, larvae and adults) is urgently required. The aim of the current study was to investigate the efficacy of various low toxicity, and potentially, integrated pest management (IPM) compatible insecticide products for their ability to control all relevant $B$. tabaci lifestages. Leaf dip treatments were used as they ensure good coverage of the leaf undersides, which is where the whitefly eggs and larvae stages are located (Buxton and Clarke, 1994).

The experiments were undertaken in the Plant Health Quarantine Entomology Laboratories based at the Central Science Laboratory, York, UK in 2006. 
A. G. S. Cuthbertson et al.

\section{MATERIALS AND METHODS}

Products and insect cultures

Bemisia tabaci were cultured under quarantine conditions in perspex cages $(60 \times 60 \times 80 \mathrm{~cm})$ on poinsettia (Euphorbia pulcherrima c.v. Lilo Pink) plants at $23 \pm 1{ }^{\circ} \mathrm{C}$ following the method of Cuthbertson et al. (2005a, b; 2008). The entomopathogenic fungus Lecanicillium muscarium was supplied as Mycotal from Koppert Biological Systems Ltd., UK. The selected insecticidal products to test were as follows: Majestik (natural plant extract, $2.5 \mathrm{~mL} / 100 \mathrm{~mL}$ water, Certis UK); Agri-50E (alginate/ polysaccharide, $300 \mu \mathrm{L} / 100 \mathrm{~mL}$, Fargo Ltd, UK); Certis spraying oil (petroleum oil, $1 \mathrm{~mL} / 100 \mathrm{~mL}$ water, Certis UK); Savona (fatty acids, $2 \mathrm{~mL} / 100 \mathrm{~mL}$ water, Koppert Biological Systems Ltd, UK); Oberon (spiromesifen, $0.05 \mathrm{~g} / 100 \mathrm{~mL}$ water, Certis UK).

\section{Leaf dipping}

Three life stages of $B$. tabaci were tested against; eggs, second instar larvae and adults. Plants were infested following the method of Cuthbertson et al. (2003) and cohorts at the desired life-stages were obtained using the methods and data of Butler et al. (1983), Bethke et al. (1991), Wang and Tsai (1996) and Cuthbertson et al. (2003, 2007). Four separate insecticide dilutions (all UK recommended dose rates) of each chemical and fungal product were prepared for replication purposes. Two poinsettia leaves containing eggs were dipped into each dilution for 10 s then allowed to air dry, before being placed within sealed petri dishes for each individual dilution of each insecticide. This procedure was repeated with leaves infested with second instar larvae. For adult studies, leaves were dipped and again allowed to air dry. Five adult whitefly were then placed on the leaf and held in position by a clip cage modelled on those described by MacGillivray and Anderson (1957). These were maintained in sealed Petri dishes. All Petri dishes were incubated at $20^{\circ} \mathrm{C}, 14: 10 \mathrm{~L}$ :D for $48 \mathrm{~h}$. Control tests for each lifestage were also carried out using $0.02 \%$ solution of the non-ionic wetting agent Agral (Syngenta Crop Protection Ltd., UK; active ingredient: alkyl phenol ethylene oxide) and water as appropriate.

\section{Assessment of efficacy}

Following chemical insecticide treatment the numbers of live and dead $B$. tabaci adults and larvae were recorded after $48 \mathrm{~h}$. In the case of all the fungal treatments (larval death determined both by no movement and the presence of mycelial mass where L. muscarium was applied) and all the B. tabaci egg trials, dishes were incubated for 7 days in order to allow both the fungus to germinate (Cuthbertson et al., 2005b) and eggs to potentially hatch (Bethke et al., 1991; Butler et al., 1983; Wang and Tsai, 1996). Treated eggs were noted as live (hatched larvae) or dead (unhatched). Data underwent the non-parametric Kruskal-Wallis rank sum test to compare the effect of the different insecticides.

\section{RESULTS AND DISCUSSION}

Mortality of Bemisia tabaci eggs following leaf dipping

There was a significant difference in mortality of eggs after leaf dipping with the different active ingredients (Fig. 1). Exposure to Majestik, Savona and Certis spraying oil was followed by egg mortalities (33, 46 and $81 \%$, respectively) that were all significantly higher than the water control (Majestik and water: Kruskal-Wallis chi-squared = 4.6, $\mathrm{df}=1, P=0.03$; test; Savona and water: KruskalWallis chi-squared $=6.4$, $\mathrm{df}=1, P=0.002$; Certis Spraying Oil and water: Kruskal-Wallis chi-squared $=8.5, \mathrm{df}=1, P=0.004)$. However, no significant difference was observed for other applications compared to the water control.Oberon had no effect on the B. tabaci eggs in this study

Mortality of Bemisia tabaci second instar larvae following leaf dipping

The comparative analysis for second instar larvae indicated highly significant difference (KruskalWallis test, $\mathrm{P}<0.001$ ) between chemical treatments and the water control (Fig. 2). All of the chemical treatments resulted in over $65 \%$ mortality of larvae. Oberon caused 73 \% larvae mortality, significantly higher than the water control (Kruskal-Wallis chisquared $=12.0, \mathrm{df}=1, \mathrm{P}<0.001$ ). There was significant difference in mortality caused by Agri-50E and Majestik (Kruskal-Wallis chi-squared $=0.26, \mathrm{df}=1, \mathrm{P}$ $=0.6$ ). Dipping the larvae infested leaves in the fungus produced significantly lower larvae mortality than the chemical treatments (Kruskal-Wallis test, $\mathrm{P}<0.01$ ), but was still significantly higher than the water control (Kruskal-Wallis chi-squared $=5.1, \mathrm{df}=1, \mathrm{P}=$ $0.02)$. 
Mortality of Bemisia tabaci adults following exposure to treated leaves

Dipping of the leaves and then testing for resultant efficacy against adult $B$. tabaci generated lower mortality than that of second instar, apart from the treatment of Certis spraying oil, where complete mortality of adult B. tabaci was recorded (Fig. 3) significantly higher than the other treatments (KruskalWallis test, $P<0.001$ ). The other chemicals all resulted in significantly higher mortality of $B$. tabaci adults than the water control (e.g. Majestik and water: KruskalWallis chi-squared $=9.1, \mathrm{df}=1, P=0.003$ ).

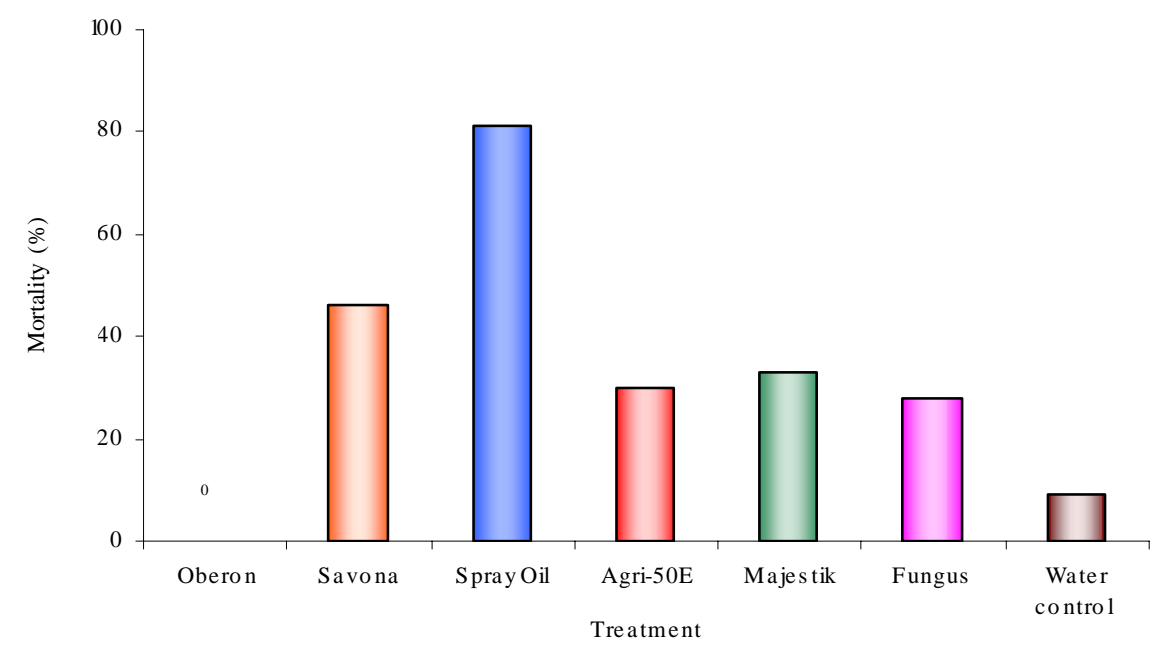

Fig. 1: The efficacy of insecticide treatments against Bemisia tabaci eggs following leaf dipping. Mortality assessed after 7 days

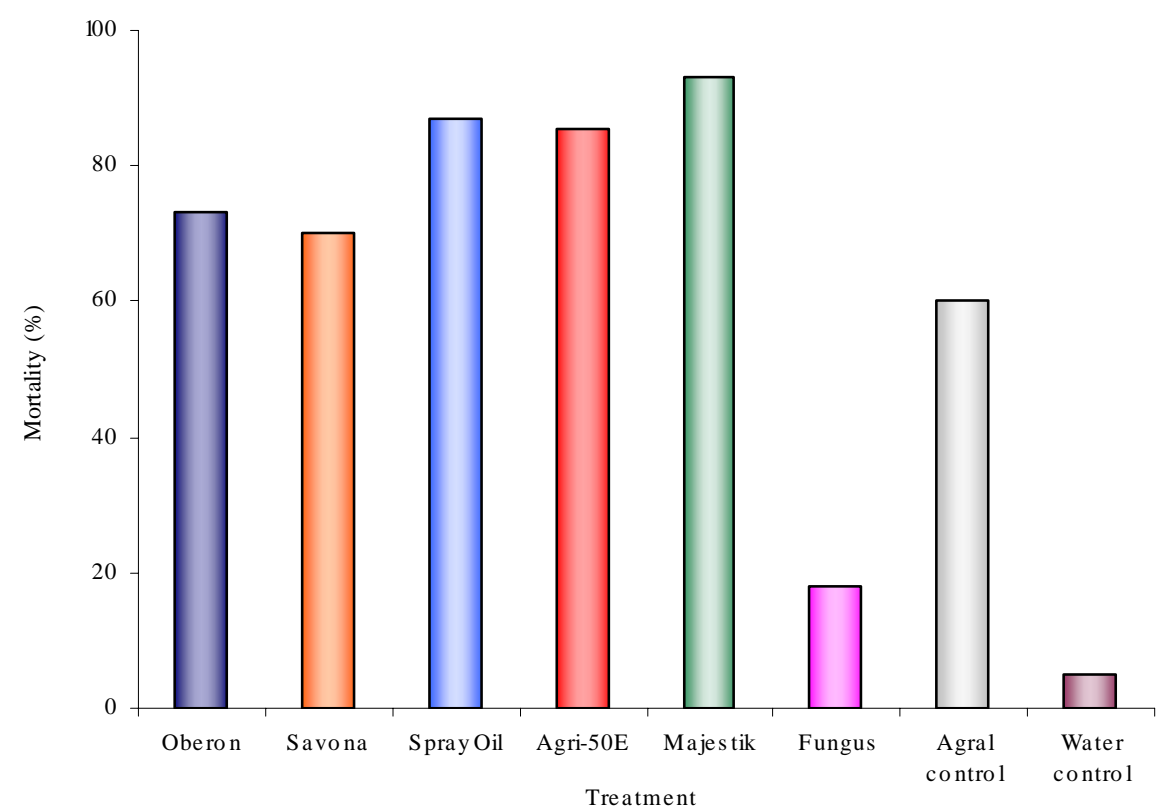

Fig. 2: The efficacy of insecticide treatments against Bemisia tabaci second instar larvae following leaf dipping; Mortality assessed after $48 \mathrm{~h}$ for all treatments except Mycotal (fungus) which was assessed after 7 days 


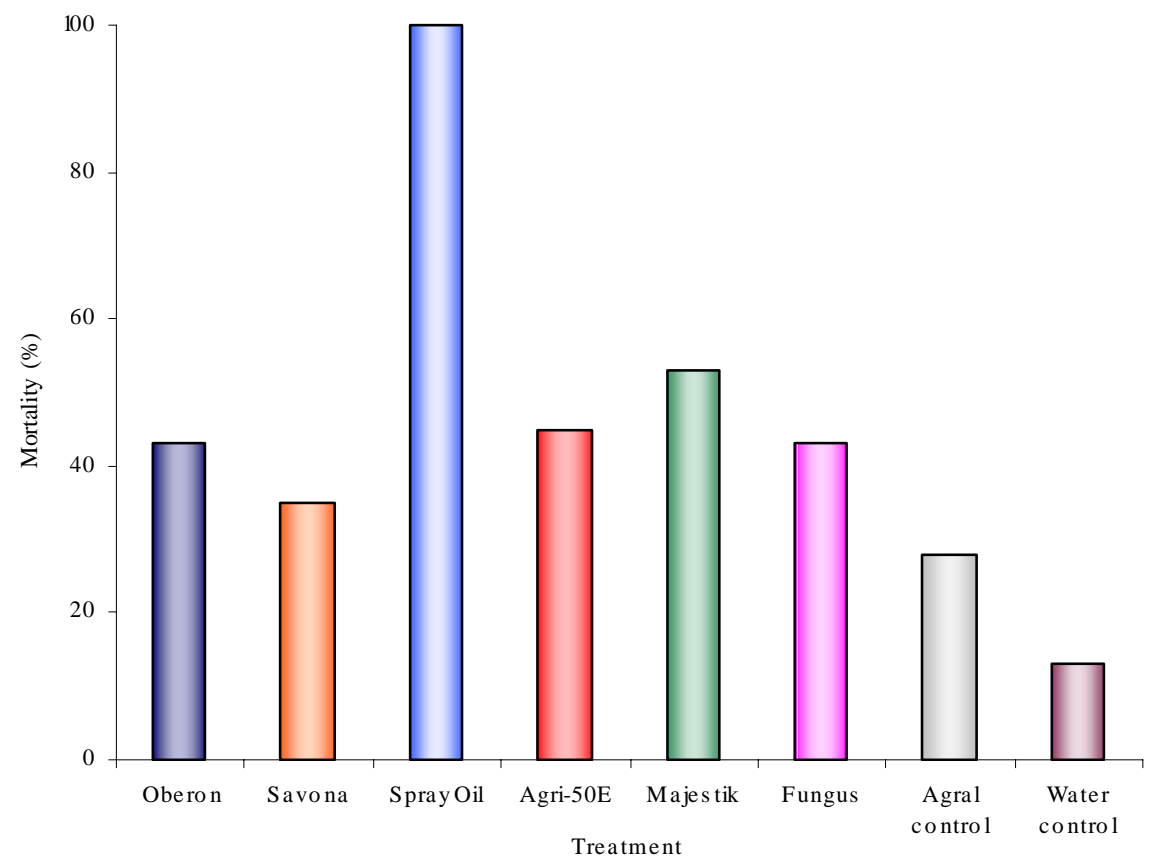

Fig. 3: The efficacy of insecticide treatments against Bemisia tabaci adults following leaf dipping; Mortality assessed after $48 \mathrm{~h}$ for all treatments except Mycotal (fungus) which was assessed after 7 days

This study, using leaf dipping as a screening method (Buxton and Clarke, 1994; Buxton et al., 2008), investigated the potential of various low toxicity chemical and fungal products for their efficacy against various lifestages of $B$. tabaci. The collected information will be added to the knowledge base of potential chemicals already used against B. tabaci within IPM strategies in the United Kingdom (Buxton and Clarke, 1994; Cuthbertson et al., 2005a).

Oberon, which has been reported as having low ovicidal properties (Nauen et al., 2005), resulted in no mortality of B. tabaci eggs following leaf dipping. Indeed, all chemicals with the exception of Certis spraying oil produced low egg mortalities. The results from this study further confirm the difficulty of eradicating egg stages. Leaf dipping against second instar and adult life stages produced higher mortality. The chemicals Majestik, Savona, Agri-50E and Certis spraying oil all produced high mortalities of second instar larvae B. tabaci, such treatments could act as a first line of defence in dealing with a B. tabaci outbreak. Buxton and Clarke (1994) also found spray oil to provide good control of both eggs and larval $B$. tabaci lifestages. In regards, to adult whitefly control Certis spraying oil showed great potential as total mortality of adult $B$. tabaci was achieved. It is thought that Certis Spraying Oil may act directly via a toxic action when the oil penetrates the insect cuticle (Martin and Woodcock, 1983) and indirectly by simply depriving the insects of oxygen (Buxton and Clarke, 1994).

Further work will now be to test the selected chemicals for their toxicity to non-target beneficial organisms with the aim of incorporating them into IPM strategies. Certis spraying oil is known to have only a moderate effect on the whitefly parasite Encarsia Formosa (Matteoni, 1993). However, the effects of these chemicals on the many predatory mite species' and entomopathogenic nematodes available for biological control of $B$. tabaci are unknown. 


\section{ACKNOWLEDGEMENTS}

The authors thank Koppert Biological Systems Ltd, (UK) for supplying the formulation of Lecanicillium muscarium; Certis UK for the supply of chemical products used in this study and Mr Richard Natt (Fera Horticultural Manager) and his team for the provision of plant material. The work was funded by Plant Health Divison, Defra. Bemisia tabaci were held under quarantine license number: PHL 251B/5328(02/2006) Amended (04/2006).

\section{REFERENCES}

Ahmad, M.; Iqbal, A. M.; Ahmad, Z.; Denholm, I., (2002). Cotton whitefly (Bemisia tabaci) resistance to organophosphate and pyrethroid insecticides in Pakistan. Pest Manage. Sci. 58 (2), 203-208 (6 pages).

Alegbejo, M. D., (2000). Whitefly transmitted plant viruses in Nigeria. J. Sustain. Agri., 17 (2), 99-109 (11 pages).

Bethke, J. A.; Paine, T. D.; Nuessly, G. S., (1991). Comparative biology, morphometrics and development of two populations of Bemisia tabaci (Homoptera: Aleyrodidae) on cotton and poinsettia. Ann. Entomol. Soc. Am., 84 (4), 407-411 (5 pages).

Butler, G. D.; Henneberry, T. J.; Clayton, T. E., (1983). Bemisia tabaci (Homoptera:Aleyrodidae): Development, Oviposition, and Longevity in relation to temperature. Ann. Entomol. Soc. Am., 76 (2), 310-313 (4 pages).

Buxton, J.; Clarke, A., (1994). Evaluation of insecticide dips to control Bemisia tabaci on poinsettia plants. Pest. Sci. 42 (2), 141-142 (2 pages).

Buxton, J.; Cuthbertson, A. G. S.; Cannon, R. J. C., (2008). Rooting out tobacco whitefly. Horticultural Development Council News, February, 22-23 (2 pages).

Cahill, M.; Byrne, F. J.; Denholm, I.; Devonshire, A. L.; Gorman, K. J., (1994). Insecticide resistance in Bemisia tabaci. Pest. Sci., 42 (2), 137-139 (3 pages).

Cahill, M.; Gorman, K.; Day, S.; Denholm, I., (1996). Baseline determination and detection of resistance to imidacloprid in Bemisia tabaci (Homoptera: Aleyrodidae). B. Entomol. Res., 86 (2), 343-349 (7 pages).

Cannon, R. J. C.; Eyre, D.; MacLeod, A.; Matthews, L.; Malumphy, C.; Cheek, S.; Bartlett, P. W., (2005). Interceptions and outbreaks of Bemisia tabaci in the UK. The BCPC International Congress - Crop Science and Technology 2005. Congress Proceedings Vol. 2: 10071012. ISBN 1901396657

Cheek, S.; MacDonald, O., (1994). Management of Bemisia tabaci. Pest. Sci., 42 (2), 135-137 (3 pages).

Cuthbertson, A. G. S.; Head, J.; Walters, K. F. A.; Gregory, S. A., (2003). The efficacy of the entomopathogenic nematode, Steinernema feltiae, against the immature stages of Bemisia tabaci. J. Invertebr. Pathol., 83 (3), 267-269 (3 pages).

Cuthbertson, A. G. S.; Blackburn, L. F.; Northing, P.; Luo, W.; Cannon, R. J. C.; Walters, K. F. A., (2008). Further compatibility tests of the entomopathogenic fungus Lecanicillium muscarium with conventional insecticide products for control of sweetpotato whitefly, Bemisia tabaci on poinsettia plants. Insect Sci., 15 (4), 355-360 (6 pages).

Cuthbertson, A. G. S.; Mathers, J. J.; Northing, P.; Luo, W.; Walters, K. F. A., (2007). The susceptibility of immature stages of Bemisia tabaci to infection by the entomopathogenic nematode Steinernema carpocapsae. Russ. J. Nematol., 15 (2), 153-156 (4 pages).

Cuthbertson, A. G. S.; Walters, K. F. A.; Deppe, C., (2005a). Compatibility of the entomopathogenic fungus Lecanicillium muscarium and insecticides for eradication of sweetpotato whitefly, Bemisia tabaci. Mycopathologia, 160 (1), 35-41 (7 pages).

Cuthbertson, A. G. S.; Walters, K. F. A.; Northing, P., (2005b). The susceptibility of immature stages of Bemisia tabaci to the entomopathogenic fungus Lecanicillium muscarium on tomato and verbena foliage. Mycopathologia, 159 (1), 23-29 (7 pages).

De Barro, P. J., (1995). Bemisia tabaci Biotype B: A review of its biology, distribution and control. CSIRO Technical Paper No 33. Canberra: CSIRO. 58.

Dennehy, T. J.; Williams, L., (1997). Management of resistance in Bemisia in Arizona cotton. 51 (3), 398-406 (9 pages).

Fransen, J. J., (1994). Bemisia tabaci in the Netherlands; Here to stay? Pest. Sci., 42 (2), 129-134 (6 pages).

Gerling, D.; Motro, U.; Horowitz, R., (1980). Dynamics of Bemisia tabaci (Gennadius) (Homoptera: Aleyrodidae) attacking cotton in the coastal plain of Israel. B. Entomol. Res., 70 (2), 213-219 (7 pages).

Gerling, D.; Mayer, R. T., (1996). Bemisia: 1995 Taxonomy, biology, damage and management. ntercept, Ltd., Andover, UK.

Jones, D. R. (2003). Plant viruses transmitted by whiteflies. Eur. J. Plant Pathol., 109 (3), 195-219 (5 pages).

Landa, Z.; Osborne, L.; Lopez, F.; Eyal, J., (1994). A bioassay for determining pathogenicity of entomogenous fungi on whiteflies. Biol. Contr., 4 (2), 341-350 (10 pages).

MacGillivray, M. F.; Anderson, G. B., (1957). Three useful insect cages. Can. Entomol., 89 (1), 43-46 (4 pages).

Martin, H.; Woodcock, D., (1983). The Hydrocarbon Oils. In: The Scientific Principles of Crop Protection. $7^{\text {th }}$ Ed., Edward Arnold, London, 212-220 (9 pages).

Matteoni, J., (1993). Chemical effects on greenhouse biological control agents. Grower Talks, 81-85.

Naranjo, S. E.; Ellsworth, P. C.; Chu, C. C.; Henneberry, T. J., (2002). Conservation of predatory arthropods in cotton: Role of action thresholds for Bemisia tabaci (Homoptera: Aleyrodidae). J. Econ. Entomol., 95 (4), 682-691 (10 pages).

Nauen, R.; Schnorbach, H. J.; Elbert, A., (2005). The biological profile of spiromesifen $\left(\right.$ Oberon $^{\circledR}$ ) - a new tetronic acid insecticide/acaracide. PflanzenschutzNachrichten Bayer, 58 (3), 417-440 (24 pages).

Nomikou, M.; Janssen, A.; Schraag, R.; Sabelis, M. W., (2001). Phytoseiid predators as potential biological control agents for Bemisia tabaci. Exp. Appl. Acarol., 25 (4), 271-291 (21 pages).

Osborne, L. S.; Landa, Z., (1992). Biological control of whiteflies with entomopathogenic fungi. Fla. Entomol., 75 (4), 456-471 (16 pages). 
Prabhaker, N.; Coudriet, D. L; Meyerdirk, D. E., (1985). Insecticide resistance in the sweetpotato whitefly, Bemisia tabaci (Homoptera: Aleyrodidae). J. Econ. Entomol., 78 (4), 748-752 (5 pages).
Wang K. H.; Tsai, J. H., (1996). Temperature effect on development and reproduction of silverleaf whitefly (Homoptera:Aleyrodidae). Ann. Entomol. Soc. Am., 89 (3), 375-384 (10 pages).

\section{AUTHOR (S) BIOSKETCHES}

Cuthbertson, A. G. S., B.Sc., Ph.D., Senior research entomologist at The Food and Environment Research Agency in York, England, UK. Email: andrew.cuthbertson@fera.gsi.gov.uk

Blackburn, L. F., B.Sc., Research entomologist at The Food and Environment Research Agency in York, England, UK. Email: lisa.blackburn@fera.gsi.gov.uk

Northing, P., B.Sc., M.Sc., Applied Entomology team leader at The Food and Environment Research Agency in York, England, UK. Email: phil.northing@fera.gsi.gov.uk

Luo, W., B.Sc., M.Sc., Ph.D., Environmental statistician at The Food and Environment Research Agency in York, England, UK. Email: weiqi.luo@fera.gsi.gov.uk

Cannon, R. J. C., B.Sc., Ph.D.,Senior plant health consultant at The Food and Environment Research Agency in York, England, UK. Email: ray.cannon@fera.gsi.gov.uk

Walters, K. F. A., B.Sc., Ph.D., Phytophthora research team leader at The Food and Environment Research Agency in York, England, UK. Email: keith.walters@fera.gsi.gov.uk 